\title{
International Cooperation, Homosexuality and AIDS in Mozambique
}

\section{Francisco Paolo Vieira Miguel*}

\begin{abstract}
The current paper is an ethnographic study of an international cooperation project between an international organisation for the fight against the HIV/AIDS epidemic and the organisation LAMBDA, the largest LGBT NGO in Mozambique. The objectives of this paper are, firstly, to demonstrate how due to the international flow of financial resources attached to certain concepts and agendas, these projects end up somehow institutionalising a homosexuality project in Mozambique, in addition to reviving potentially neo-colonial practices. It also seeks to demonstrate how external bureaucratic practices can clash with local cultural practices, in what has been called 'NGOisation.'
\end{abstract}

Keywords: international relations; cooperation; Africa; Mozambique; AIDS; ethnography; anthropology.

\section{Introduction}

The way the idea of 'homosexuality' has been historically constructed in Europe refers to a category of thought that is not found in nature and, therefore, is neither universal nor static, nor timeless (Foucault 1988; Bleys 1995; Rubin 2018). In other words, a homosexual subjectivity (that is, as opposed to heterosexual one; someone who often describes his/ her desire or identity as innate and immutable; who frequently drives his/her homoerotic practices throughout life; who directs his/her primary affection exclusively to the same sex and/or that carries with it the tendency to adhere, more or less, in its corporeality to the signs of the opposite gender, as modern and hegemonic homosexuals currently are thought) is not universal, even though sexual and affective practices among people of the same sex can virtually be (Padgug 1990: 60; Murray and Roscoe 1998: 271; Neill 2009: 11).

Thus, in order for 'homosexuality' or the (modern) 'homosexual subject' to gain social existence, a political-epistemological effort or a process of 'institutionalisation' is needed (Mary Douglas 1986). This phenomenon historically occurred at certain times and places

University of Brasilia (UnB), Brasilia-DF, Brazil; fpvmiguel@gmail.com. ORCID iD 0000-0003-1173-9727. 
in human experience, without necessarily coinciding in their meanings. ${ }^{1}$ By 'institution,' Mary Douglas referred to strong social conventions (Douglas 1986: 46) that depart from the analogy with the body and with the (sexual) division of labour (Douglas 1986: 49) based on nature and reason (Douglas 1986: 45), which are the continuous results of a classification dispute developed by social groups (Douglas 1986: 63) that need to 'forget' what doesn't suit them (Douglas 1986: 112) and that, to be stable, need to camouflage their socially constructed character (Douglas 1986: 92). In her own words:

There needs to be an analogy by which the formal structure of a crucial set of social relations is found in the physical world, or in the supernatural world, or in eternity, anywhere, so long as it is not seen as a socially contrived arrangement [...] Any institution that is going to keep its shape needs to gain legitimacy by distinctive grounding in nature and in reason: then it affords to its members a set of analogies with which to explore the world and with which to justify the naturalness and reasonableness of the instituted rules, and it can keep its identifiable continuing form. Any institution then starts to control the memory of its members; it causes them to forget experiences incompatible with its righteous image, and it brings to their minds events which sustain the view of nature that is complementary to itself. It provides the categories of their thought, sets the terms for self-knowledge, and fixes identities (Douglas 1986: 48-112).

In my ethnographic research, I tried to demonstrate anthropologically not only the various processes of the institutionalisation of homosexuality in the history of Mozambique (within the government, the media, the LGBT movement, religion, families, and in the lived experiences of my interlocutors) but also sought to historically reconstruct the origin of LAMBDA, the largest and most active LGBT organisation in the country, and some of its current and historical guidelines. The goal was to understand how LAMBDA, in its activist activities, would act as one of these agents of the 'institutionalisation' of homosexuality in Mozambique. ${ }^{2}$

Given the great volume of data that could be extracted from the various fronts of activism that LAMBDA undertakes, ${ }^{3}$ I choose to analyse in this article only the 'TLPFA' Project. It is one of the projects funded by international partners, aimed at combating the epidemic of HIV/AIDS in Mozambique, targeting the local LGBT communities. This activity is LAMBDA's biggest focus, highlighted upon an analysis of the organisation's financial resources, workload and number of people involved. My objective here will be to demonstrate: 1) how, due to the international flow of financial resources attached to certain concepts/agendas, these projects end up somehow institutionalising a homosexuality project in Mozambique, in addition to reviving potentially neo-colonial practices; 2) how external bureaucratic practices clash with local cultural practices. 


\section{The TLPFA Project}

I closely followed one of the four projects that were being carried out in the organisation at the time of my fieldwork. For the purpose of anonymising its sponsoring donor, the project will be referred to here as 'The Little Prince for AIDS' or 'TLPFA Project.' In addition to other similar calls for proposals already in existence aimed at other countries, the TLPFA Project was launched in Mozambique calling on local (and international) organisations to submit proposals for action, with a funding budget of up to US $\$ 2 \mathrm{~m}$. The announcement encouraged organisations to form consortia(s) in order to compete for the fund. According to one of the employees directly involved in the process, LAMBDA's first attempt of applying to this fund was unsuccessful, as the proposal focused too much on LGBT 'advocacy', that is, on visibility, civil rights, or combating stigma. For that reason, it was rejected by the donor institution, whose specific object of action is the fight against the HIV epidemic, despite having a gay celebrity as an owner.

When I asked one of the LAMBDA employees who were involved in these internationally funded projects what was the greatest requirement of these partners and what exactly they wanted when financing this type of project, he replied:

- There is a line that is driven by HIV. This line that is driven by HIV, the interest is really HIV. They are interested in service provision. 'Are people receiving condoms?'; 'Are people getting lubricants?'; 'Are people receiving messages?'; 'Are people being tested?'; 'Are [HIV] positive people being referred to treatment?' This is the focus of partners looking at the issue of HIV. They are not concerned with other issues such as stigma, discrimination, human rights, they are not there... (Luiz, interview, 2018). ${ }^{4}$

Already familiar with the TLPFA Project and believing that it did not fit perfectly in the description given by my interlocutor, I asked him if this project was not, in fact, a little different, as it would meet these two expectations (both the technical aspects of the epidemic and combating its root causes such as the discrimination against LGBT people). He agreed:

- Yes, yes. The [TLPFA Project] has this strong component of human rights. That is why they are investing in this pillar of advocacy, they are investing in creating a favourable environment, training health providers, so that they provide a friendly service. These community houses that we are establishing, to bring a little more joy and freedom to the community. But on the other hand, there is this vein of HIV, which is also required of us. The guarantee that people are being tested. Positive ones are being referred for treatment... (Luiz, interview, 2018).

Intrigued by the relationships that are established between donors and recipients, between both the expectations of the different actors that do not always coincide, I asked 
Luiz what it was like for him to work with these partners. For him, the ideal partners are the Nordics (and he lists them: 'Swedes, Dutch, Danes') because they are generally the most 'flexible' and would have 'a great interest in understanding the processes.' In other words, they would be more interested in the 'human side', in 'advocacy.' With regards to partners in USA, this would not be the case, since such partners would only be concerned with diseases, 'numbers' and 'goals.' According to Luiz, the Americans would not be interested in issues such as 'public education,' 'understanding the process,' 'awareness raising' etc.:

- But the American is not interested in that. The indicators are crystal clear: 'How many people are reached?'; 'Of which, how many tested?'; 'Of which, how many in treatment?' The rest is foolishness... $\mathrm{He}$ is not interested at all. [...] I worry a lot because in the country, right now, the American is the partner that is putting more resources for HIV. [...] Even the Ministry of Health, giving the support it has, depends a lot on the American government. So, for me it is ... I feel that, well, they are making a big investment, but it is particularly important that things like stigma, discrimination ... Several times here at LAMBDA people who were kicked out of home knocked on the door, people who need answers ... Wow, someone was bullied, suffered aggression, needs an answer. There is a professor who is homophobic, that institution that does not accept ... We need interventions in this! (Luiz, interview, 2018).

Here, already the first issue to touch on Mozambican LGBT activism and that of other countries on the African continent in depth (Hoad 2007) arises: the emphasis placed by international partners on the sexual health of African LGBT people (and within these, more particularly men who have sex with men $\left(\mathrm{MSM}^{5}\right)$ ) to the detriment of 'advocacy' projects, scientific research, or activities that promote LGBT entertainment or visibility of these groups in their respective countries. These two causes are considered by many Mozambican activists equally relevant. ${ }^{6}$ On many occasions, I have heard much on the criticism from Mozambican LGBT activists that these projects gave importance only to the sexual health of Africans - and particularly MSM (Chipenembe 2018: 25), as if this were the only facet of an LGBT's life in Africa.

At an LGBT event that took place on 14 July 2018 at the US Embassy in Maputo, which I had the opportunity to attend, a LAMBDA activist stated at one point that not only the HIV agenda, but also its focus on the MSM population was externally 'imposed':

- My fear is HIV/AIDS. International agencies brought the agenda. There, in NYC, I do not know where, they invented the acronym MSM, but it is not a good one. There is a lot of money out there. But this MSM focus on HIV takes away the visibility of other people from the acronym. This agenda is imposed. Money comes with 'label' [mandatory expense]. It is a backwards step to be looked at 
only as sexual beings and the drowning out of other people of the acronym (Sousa 2018).

Similar complaints were raised in one of the sessions of MenEngage, an international academic event on African masculinities held at the University Eduardo Mondlane in Maputo, on 25 April 2018. In it, LAMBDA employees, a lesbian and another who self-identifies as 'queer,' complained to colleagues from foreign organisations from Kenya and Uganda that international donors, being too preoccupied with sponsoring AIDS projects, only favoured MSM to the detriment of lesbians, as the former would supposedly be more vulnerable than the latter. ${ }^{7}$

In fact, the issue of the HIV/AIDS epidemic in Africa - and particularly in Mozambique - is serious from the point of view of epidemiology. Mozambique has approximately $11.5 \%$ of its population living with HIV, making it the $8^{\text {th }}$ largest incidence in the world (UNICEF 2014: 22). Therefore, the HIV epidemic is not a vestigial issue, in which the focus of European donors would derive only from the historical racism that hypersexualised the blacks from the continent (Lyons and Lyons 2003). There are legitimate reasons, based on epidemiology, to choose the HIV epidemic in the country as a priority target. Even so, the emphasis of these international cooperation projects on sexuality - to the detriment of the beneficiaries' other fields of life - is undeniably a practice consolidated on certain racist premises about Africa and its black inhabitants.

Neo-colonial practices are a constant for these North American and European organisations when dealing with local African organisations. As an example, I highlight the speech of a Mozambican activist in an interview about external impositions, including the organisational charts of local organisations:

- There was an episode that [the director] did not tolerate. It was at the time that he made it clear to everyone, 'Calm down! We are partners. There is no...' I mean, 'I demand because I have the resources and you must obey'. This is not how it works. So, I think this is quite common. I come from another organisation. I know the situation of several organisations. And it is common for these [foreign] partners to arrive at the [local] organisation to order. And even to determine what each one should do in the organisation.

- To change the organisation chart ...

- Yes, Yes, Yes. Including the job structure, bringing people to join the organisation... It is quite common, quite common. It is quite common. And they already tried with us (Luiz, interview, 2018).

At another point in the conversation, the same employee reveals that this propensity to change the local organisational charts could be partially explained by the view of some international partners that, fearful in light of recent cases of corruption in other Mozambican organisations, carry out detailed inspection based on suspicion. According to Luiz, they therefore imply a fear that money could be diverted. He then complains that 
these international partners often treat Africans as 'a bunch of 'thieves.' It is not trivial, however, that the imposition of reorganisation of the vacancies/functions of the local employees takes place to meet the interests of these international collaborators in providing job opportunities to people of European, North American or even other Western descent and contexts, reviving a job market similar to the ways of the colonial period.

But racism and neo-colonialism are not only perceived by those who suffer them, but sometimes also by the international partners, who perceive themselves to be maintaining these practices. I saw this in the case of one of the European partners linked to the TLPFA Project. According to a second partner (also white and European, who was my interviewee), the former had confessed her colonial discomfort in exercising her role of overseeing the project's activities as she had to keep asking questions to the HIV-positive patients in the hospital - many of whom were in precarious health conditions, which often required them to overly expose themselves.

Thus, on the one hand these international organisations contribute to the fight against the HIV/AIDS epidemic in local LGBT populations to a certain extent. Yet, on the other hand, they continue to sexualise not only LGBT people but Africans in general, and particularly institutionalising through the economic and symbolic power they hold a specific idea of homosexuality on the continent. In other words, the strong connection that has been forged in the West between AIDS and homosexuality, especially among men, ends up being exported in these active cooperation projects, causing African LGBT organisations to deal with a problem that, as opposed to what took place in the West, is only marginally theirs, ${ }^{8}$ as long as Mozambican activists would consider more important to act on other subjects. Fortunately, as the LAMBDA official mentioned, there are other minority partners, interested in other agendas:

- [...] Fortunately, we [from] LAMBDA, our luck is to have other partners. Other partners who do not have this HIV line vigorously. They are more focused on the promotion of human rights. Which allows us, in a way, to combine 'Okay, we have these people who are interested in HIV, let us go to HIV. But we have this side that is interested in rights, in freedom, that we are going to work with this group' (Luiz, interview, 2018).

Thus, even in projects aimed directly at HIV, LAMBDA staff finds creative ways to use resources to meet both external and internal demands. For example, investing money in a 'safe space' that serves both for the socialisation of the local LGBT community - which lacks such public or private spaces - and for the health services that the project requires:

- [...] what we justified at the time is that safe spaces will help us to create demand. It is a space where the community goes, they will feel good, and in this space, we will offer testing services onwards. We are resolving two issues at the same time. This side of socialization ... (laughs) [...] We are going to have our parties, which is what the community wants, but 'ok, they are concerned with the issue of 
HIV, okay, we have a room there where we will offer testing' (Luiz, interview, 2018).

I also had the opportunity to interview the main European official responsible for the TLPFA Project in Mozambique by Skype, whom I had already met in person during his visit to the opening of one of the two safe spaces financed by this project in Choupal, a neighbourhood on the outskirts of Maputo, the country's capital. In a relatively quick formal interview, I was able to identify in these international partners a certain disregard for the consequences generated in Mozambique by the type of agenda imposed by these donors. This disregard was observed particularly in terms of imported nomenclatures, ${ }^{10}$ echoing a concern already pointed out by other researchers (Leap 2002: 146). He stated:

- [...] you know, if we support organisations, we will hope that they help whoever needs... support to get treatment. But, of course, as you know and I know, men who have sex with other men or 'gay men' - whatever you want to call them - are at higher risk of HIV. So, it makes sense to have programmes that specifically try to get men like that in. But I do not think it really matters what they call each other. The interest should be... to help people who need help, services... and to help people with HIV to get HIV treatment. [...] I think it is a difficult balancing for LAMBDA - and how they communicate with the people they serve. Whether they call it MSM or LGBT... I think the advantage of LGBT... I think it is a better way of speaking. How they identify. The disadvantage of LGBT is that... maybe some people... as you said do not even think of themselves as LGBT. And, so, I think it is not an easy thing to... It is a good question. I think that from our perspective, we just want to make sure that... you know, people can get the help that they need and so... we hope that... and the treatment works and the process... so, whatever makes it happen I think is a good thing (Patrick, interview, 2018, emphasis by the author).

At another point in the conversation, I insisted not only on the issue of the focus on the 'MSM' population, but I also tried to extract from Patrick if there was any reflection already internally made about his work practices, about the logics - possibly neo-colonialist - behind what he did at work:

So, I think for us, we want to make sure people get health care... from the populations that are currently not getting health care - specifically HIV. Because... I found I lost a lot of them... I lost, you know, friends and things like that to HIV. So, I think that if you consider that... you know, we are supporting people financially to help other people to get health care... I mean... Yeah, that is what we do. Now, whether that is like paying folks to [change cultural patterns]. I mean, inevitably people are doing things they would not have done had the 
programme not been funded - but I do not know what is beyond that. We try to avoid... our partners can always make suggestions to us about how things can best work in their local contexts because obviously they know how the local contexts work - we do not have an office in Mozambique, we are not very involved really in the details of how they do things, things like that (Patrick, interview, 2018, emphasis by the author).

Hence, it is possible to perceive a certain limitation in the understanding of international partners, even for those organisations that are relatively more open to local cultural issues, that are delegated to local partners. Once, another European involved in this project confessed to me how excited she was for working in the field for the first time, since in her own words, 'Working here, directly with them, is very different from what we planned there at the [European] office.' What my own experience in Mozambique shows is that the lack of knowledge about the realities limits the achievements in programmes to prevent the HIV/AIDS epidemic. For example, hearing a sex worker and trans community agent from the TLPFA Project saying at a LAMBDA event that between a high monetary value offered by a client for having unprotected sex and the use of condom, she would choose the former ${ }^{11}$ Furthermore, reflections on the impact of projects like this on the sexualising objectification of African LGBT people is not suggested or even addressed when asked. Patrick, the main European official responsible for the TLPFA Project in Mozambique, just reaffirmed the importance of offering the possibility of diagnosis and treatment to those who, without them, would probably not have it.

Regarding the specific term 'MSM,' a community agent from LAMBDA elaborated a complaint in an interview with me, in which it was clear that, for him, the term is pejorative because it disregards the affection encountered in his relationships, and instead, just sexualises them:

- 'MSM', men who have sex with men ... I am not a 'man who has sex with a man'. I am not an adventurer. I have sexual intercourse for affection! So, I cannot be called a 'MSM'. [...] 'Man who has sex with a man'? Someone who found me there, had sex with me and left. So, he is the curious, the MSM. MSM is not an acceptable term in our community. I say, I do not accept that term. MSM ... we cannot be [using] the [term] 'MSM', for example, to talk about homosexual people. [...] I do not want it to be used for me. I also do not want anyone to use it for other people who are from the community. There is MSM. MSM, I call curious people, for example. Because he was drunk, he was there with a homosexual, he had the intention. In fact, he was either seduced or he seduced, realizing that this person had a relationship. So, at that time, he wanted to experiment, or whatever, he just did (Caetano, interview, 2018). 
The nomenclature issue is not trivial, since it carries a series of assumptions, expectations, and ways of being in the world with it that do not necessarily coincide with local logic (Leap 2002: 128). Let us see below how the dimension of the name that is used for these new subjectivities that arise is a factor of disputes and of a possible linguistic and cultural transformation in the Mozambican context.

\section{Distributing condoms, testing, and naming}

Luiz was one of the most senior employees at LAMBDA responsible for all projects on the HIV/AIDS issue in this organisation. At the time of my interview with him, he was a 40 year-old man who came from a province in the north of the country and, despite not being an 'LGBT' person himself, he already had more than a decade of experience in the issue of AIDS in intersection with LGBT issues. It was late at night, and after another tiring day at work, he finally granted me an interview. He was behind his desk, in the already empty room he shared with other colleagues, on the second floor of one of the two huge houses of the LAMBDA headquarters, in the central District of Maputo. I began by asking him about his professional career. He said that he started to work for a Mozambican organisation that worked in the field of HIV prevention. At a certain point around 2006, after debates about the lack of effectiveness of the HIV prevention programmes, it was concluded that gender issues should be included in them.

In this vein, he and some colleagues from the same organisation attended the same training in Arusha, Tanzania, sponsored by two Swedish organisations focused on these issues. It was there that Luiz, who is not a homosexual, said he had his first contact with the issue of sexual orientation.

- So, it was there - about 12 or 13 years ago - that I learned about sexual orientation. It was the first time that I started listening about [it]. Well, it was just a new topic, I did not have much knowledge at the time. And then we went to be trained as trainers. So, the responsibility was to go back to the country and start and train the first group of trainers. We would have the mission to provide training in HIV at the provincial level but making this connection with issues related to gender. We discussed the norms, values, rights, and so on. And when I came back from Arusha, I came back a completely different person [compared to who] I was (Luiz, interview, 2018).

At this point, we can already see how these international organisations operating in Mozambique, most of which, of European origin, were (and still are) fundamental in offering a series of new perspectives on various subjects to those activists in developing countries. ${ }^{12}$ In other words, they are fundamental in 'institutionalising' some issues. When I asked him why he returned 'completely different' from that experience in Tanzania, Luiz replied: 
- Firstly, because I was a person, for example, very [much] against abortion. And I remember that before the training, I had made some comments - I think it was on a Facebook post, I really do not remember who it was - judging! Because someone was advocating abortion. Safe abortion. And I, at the time, made comments that today I deeply regret. Because I practically ran over the rights that [the] person had to decide whether to keep the pregnancy or not ... But I did not have it, I did not have the knowledge I acquired after that training (Luiz, interview, 2018).

However, the new perspectives go far beyond the issue of abortion. They range from how best to combat the HIV/AIDS epidemic by offering a new lexicon to deal with subjects hitherto - by many Mozambicans, unspeakable, such as homosexuals. This first contact with the issue of sexual orientation, according to Luiz, was also quite transformative. When he returned from training in the neighbouring country, Luiz needed to replicate the knowledge acquired and, in that sense, he did a series of 'training courses' across the country. One of these, in northern rural Mozambique, affected him forever and is extremely illustrative for the argument of this paper:

- And one thing left a mark on me - I think it was in 2009, not 2008 or 9, I do not remember well. We went to a district in the countryside of Nampula to talk about sexual orientation, to talk about homosexuality and an old woman appeared and when I spoke about the topic she said 'Wow, my son, now I understand. I had a brother who never married. We tried to force him, we forced him, but he never accepted it. He said that when he was close to women, he felt bad, there was a spirit that came, took him, and hurt him. But I always saw him with men, until his death. He never met women; he never had this affection. But I did not know. Only now that you are saying this, I begin to understand.' Why did it leave a mark on me? It left a mark on me because we were not in a big city. We were inland. And the person who was speaking was an elderly woman. I think she did not know how to read or write, but she remembered this episode, I mean... Then I ended up using this testimony in other trainings, including those in big cities, because there was a chain that said, 'Ah, it's a matter for cities. This is for whites, there is no such thing among us.' Henceforth. I always... I remember this story that happened in the countryside, I always used it in other trainings (Luiz, interview, 2018).

Thus, the old woman from the North Mozambican countryside, according to Luiz, probably illiterate, reported having a brother who, for her, fit the profile of the homosexual subject to which, for the first time in her life, she was introduced by someone. We noticed in this testimony that in that context, until then, there did not seem to be a 
name to identify a subject who combined celibacy, aversion to women and above-average male affections. For this guy, socially maladjusted as he was, there was no name in the native language, there was no specific identity: he was simply, at the same time, a celibate, someone who had an affective/sexual aversion to women and someone who always stayed in the company of men. The man himself - according to his sister - attributed the cause to the spirits. But the composition of a specific subjectivity centred on sexuality did not seem to exist. The new subject that appeared in Luiz's cognitive and linguistic apparatus, through Swedish organisations, would appear in the reality of that old woman from the northern interior of the country through an easily demonstrable chain, to account for his brother, a subject who, until then, was just a stranger.

Situations like this one appear in the Mozambican ethnography (Chipenembe 2018: 117-118) and in conversations I had with Professors from the University Eduardo Mondlane, that revealed for the first time considering the possibility of sponsorship and the experience of 'living together' among men, so commonly observed since the colonial period, as homosexual and homo-affective experiences (Miguel 2019: 85). According to one of them, 'the Mozambican is not trained to see it.' But if one of the teachers says that his inability to see homosexuality is due to the fact that he is someone who came from the 'province', that is, from the rural countryside where these issues supposedly do not exist and which he would not have been 'trained' to identify, Luiz would probably answer that even if there is no name, the subject is there. The same applies to his homoerotic practices; having the 'knowledge' about the issue would be sufficient to be able to identify it. Just as it happened in the case of the interaction between the old woman and himself.

\section{NGOisation}

Another ethnographic issue that I highlight here in terms of this type of action by LAMBDA and international organisations that focuses on the sexual health of the community has to do with 'NGOisation' (Dearham 2013), that is, with the bureaucratization of the LGBT movement. In Mozambique, I observed particularly how this process of 'NGOisation' comes up against an important value to Mozambican and other African subjects: silence and discretion regarding their sexual lives was observed, especially with regard to homoerotic practices included (Epprecht 2013; Gaudio 2009; Dankwa 2009; Kendall 1998; Nyanzi 2013; Miguel 2014, 2019; Murray 1998).

First, it is necessary to explain more deeply how the TLPFA Project works. With TLPFA funding, LAMBDA selects local community agents - mostly LGBT youth - to do an ongoing job of identifying and monitoring other LGBT people in certain regions of the city and metropolitan regions. ${ }^{13}$ These agents, who work for paid remuneration, receive not only theoretical training on sexuality and health issues, but also materials to be distributed, such as information leaflets, condoms and lubricating gel. ${ }^{14}$

Thus, community agents, when capturing new beneficiaries and providing them with assistance, are charged by LAMBDA to fill out registration forms for these new beneficiaries. The purpose of the existence of the form is not only to enable the subsequent 
conference on whether the agents are in fact accomplishing their job with real beneficiaries; it is likewise to present real data within the project deadlines to the TLPFA; thus proving the fulfilment of the established goals. The form includes spaces for 'name,' 'sexual orientation,' 'cell phone number', among additional information about the beneficiaries. When the monitoring agents - LAMBDA employees responsible for coordinating and accompanying a group of community agents - randomly check some of these forms delivered by them, they make phone calls to the beneficiaries to find out if, in fact, the community agent provided the service. The problem is that, in order to obtain the trust of the beneficiaries, the community agents - as recommended by LAMBDA itself - often promise them discretion and secrecy both in relation to their sexuality and to their serological status. When receiving these calls from the monitoring agents - people who they in many instances did not meet in person, many beneficiaries lie to preserve their privacy, denying that they were serviced to, or that they are not LGBT. When not previously informed by the community agent about the possibility of a call, the beneficiaries almost always get angry with the agents for having disclosed their private information. ${ }^{15}$

To try to resolve the situation, LAMBDA reformulated the registration form by removing the field 'name' to introduce an alphanumeric code for each beneficiary. This would supposedly render identification more difficult.

- We eliminated it... we created the code. A few years ago, it was the name on the record. But respecting this issue of privacy, we said 'No, the name is not used.' From the name and data of the beneficiaries, a code will be generated. [...] In the form, there will be no '[Luiz].' '[L]' will appear, I do not know, anything ... There was the code. But sometimes, at random, the monitoring staff makes calls from time to time. Just to measure whether, in fact... But it is also a control mechanism to ensure that our agents who are there, are not cheating (Luiz, interview, 2018).

The problem is that the introduction of the code did not solve the dilemma between the need to verify the veracity of the information and that to respect the privacy of the beneficiaries. I want to extract from this case that a bureaucratic practice, necessary for the functioning of this type of modern organisation, which needs to fulfil numerical goals, ends up conflicting with cultural practices (or, being barred, in cases in which people no longer accept to be beneficiaries because they know they will be delivering confidential data about their sexual life) along with data on their health, and hence silence their own sexual and affective life.

Some other examples about the same dilemma could be briefly brought up, such as 1) the question of whether one of the testing and counselling services is within the LAMBDA headquarters, which would scare people who are not yet assumed to be 'LGBT' off; therefore, they would not want to be seen joining a known LGBT organisation; 2) the time and location where the mobile testing and counselling brigades would take place, in order not to expose the users who attended it in daylight and in places of high transit of people; 3 ) 
or if the cards with the result of the HIV tests should be delivered immediately after results are ready or not to the beneficiaries, as revealed by Valentina, an employee of a health institution that is LAMBDA's partner which also offers the sexually transmitted diseases testing service to the beneficiaries:

- It was like this: we delivered the card with the result. The test is done, and the patient reads it. In the act of testing, the provider teaches the patient how to read the result. So, when the result comes out, the patient is ready to understand the result. The issue was the delivery of the card because it draws other's attention. The person leaves with the card and the others outside start to [wonder the results of their colleagues] ... So, we were analysing this issue in the sense that it could be a little discriminatory. So, the conclusion we reached was that the community agent who mobilised the patient the 'beneficiary' in this case - would arrange another time to deliver the card. No more ... the patient leaves the brigade with his result already known (Valentina, interview, 2018).

These are some examples whose list could go on and on. Yet the projects carried out by LAMBDA are not only about inconsistencies between service providers and the target audience of these services. In some interviews with beneficiaries, I obtained a lot of reports about the importance of LAMBDA in their lives, not only for providing a better understanding of their existence in the world, but also for the health of their sex lives: '[They share] knowledge. They also help needy people, at least they try. [...] They welcome patients [...] They love people. The most suffering people' (Paula, interview, 2018).

\section{Final considerations}

Based on an ethnographic research carried out in 2018 in southern Mozambique, in this paper I sought to demonstrate my central arguments that the flow of financial resources and concepts, through cooperation projects established between international organisations and LAMBDA - the largest local LGBT organisation, can end up institutionalizing a 'homosexuality' project in Mozambique. Firstly, institutionalization associates certain sexual practices and identifies them with the dimension of sexually transmitted diseases in particular HIV/AIDS - to the detriment of other locally important guidelines, such as combating discrimination or establishing safe spaces for conviviality and leisure for these populations. In addition to other effects, such an emphasis on the sexual life of LGBT Mozambicans would reveal potentially neo-colonial practices, by supposing and subjecting Africans only to their sexual dimension. Finally, it was also possible to realise that, in addition to the imposition of external terminology, exogenous bureaucratic practices end up being in conflict with local cultural practices, for example, when the requirement for registration of those served is established and is in contradiction with the wide local Mozambican custom of sexual discretion. Inconsistencies between service providers and 
target audience of these services in the projects carried out by LAMBDA were observed. Moreover, in some interviews with beneficiaries, many reports about the importance of LAMBDA in their lives have indicated that not only it provides a better understanding of their existence in the world, but rather, one of their sexual lives' health.

\section{Notes}

1 Boellstorff states that 'the crucial point is that homosexuality (like any other cultural logic) 'globalizes' (or 'translocates') not as a monolithic discourse but as a multiplicity of beliefs and practices, elements of which can move independently of each other or not move at all' (Boellstorff 2005: 173). For example, in Indonesia, the confessional idea embedded in the 'epistemology of the closet' would not have had resonance between the gay and lesbi natives.

2 The field work in Mozambique consisted of a period of six continuous months in the field, from March to September 2018, in the Maputo Province. Altogether, 36 formal interviews were conducted among LGBT people and non-LGBT people, including whites, blacks and mestizos, Mozambicans and foreigners, social activists, academics, artists, urban workers, and whoever was more prone to talk about LGBT issues with me. Finally, I was able to follow, in a more systematic way, not only the day-to-day administrative work of LAMBDA but also the daily lives of some of its community agents and LGBT beneficiaries in their work on the outskirts of the city, and was able attend some of their parties, their religious services and get to know some of their homes and families.

3 From community health programs, through the production of studies and booklets for the general population, the training in several public institutions, such as police, hospitals, government, etc., the psychological assistance to LGBT and their families, and even the participation in local and international events.

4 Most of the names of my interlocutors have been replaced here to guarantee their privacy. This cannot be done for others, either because they occupy prominent positions - whose anonymity is impossible - or because they have not demanded this condition of anonymity.

5 According to Guambe, the category 'MSM' was created by epidemiologists in the 1990s, to designate men who have sex with men regardless of sexual orientation and whether or not they assume a homo or bisexual identity (Guambe 2012: 14). Theoretically, the creation of this category would broaden the focus of health policies for the prevention and treatment of sexually transmitted diseases, including AIDS, since it would remove the stigma by disassociating sexual practice from identity.

6 When I first presented my research project to the LAMBDA's official responsible for its research area in order to have his consent to start the investigation, one of the things he first suggested to me, in a warning tone, was that I should not focus in matters of LGBT health. According to him, no one else would support this monothematic anymore.

7 The phenomenon seems similar in other parts of the world (Boellstorff 2005: 147). But I brought this complaint to LAMBDA's director, who in an interview to me, replied that he recognized the problem of underrepresentation of other subjects of the LGBT acronym not only in the public served by the projects, but also in the LAMBDA boarding, in management positions. This is because, according to activists from Kenya and Uganda present at this event, international donors would no longer be willing to offer specific funds, for example, for lesbian projects in organisations with only gay men on their board. The same would apply to trans, intersex people, etc. According to them, one of the current requirements of donors would be to empower their own categories, making them manage their resources themselves. According to the director, however, it was still exceedingly difficult to find lesbian and trans people in Mozambique who were not only interested in such a job, but also qualified for it. On this issue, see Chipenembe (2018: 99-101).

8 The idea of a difference between a homosexual spread of the disease in the West and a heterosexual spread in Africa was echoed in Africa by epidemiological studies carried out by Western researchers. Western media also frequently emphasized this distinction. For example, in 1990, the American Times magazine made a long article emphasizing the heterosexual path of the epidemic in Africa as opposed to the homosexual epidemic in North America (Patton 1992: 220-1). Mozambique newspapers did the same (Miguel 2019: 131). 
9 'Safe spaces,' or 'espaços seguros,' are properties rented by LAMBDA, with funds from the TLPFA Project. One of them is on the outskirts of Maputo; the other is located in the neighbouring city Matola. The spaces were designed to function as a free environment that could welcome LGBT people for moments of leisure, socialization, parties, but also militancy activities, work meetings, distribution of sexually transmitted disease prevention supplies, and clinical testing.

10 I use the verb 'impose' because, as we saw in the concrete example of the elimination of the first LAMBDA's proposal, a project that intends to leave the dimension of the HIV epidemic and focus on other agendas is simply eliminated. Yet it is also true that, since LAMBDA managed to have the HIV-fighting project approved by the TLPFA, the latter made some concessions regarding the additional types of expenses that the project would allow - such as financing safe spaces for the LGBT population that could serve not only as testing venues, but also as meeting and party spaces - and that were not initially planned.

11 'I remember it very well. And I repeat it again. We sex workers have this possibility, this capacity. I will say again ... I do not let clients escape just because of condoms. Hey, I already know that when someone says that in the messages - worse when it is in the messages - say 'Look, I want sex with you, but I do not want to use a condom'. I question myself, me alone. 'Why is he saying at first that he doesn't want to use a condom?'; 'Isn't he infected?'; 'Or do you have a disease?' But when I want money, I am proposing to accept this story, it never comes with 'five hundred' [low amount of money], right, it always proposes a high value. So, I, I do not have that condom negotiation thing. I will go with a condom, if you do not want to, leave it. This is not the time to do it. Unless I see that this person is remarkable, he is very weak, then I can deny it. But he is physically, openly, in good health, I believe that I will not [deny it]' (Jessy, interview, 2018). To understand more the perspectives of the 'manas' of Maputo, see Mugabe (2019).

12 Needless to say, the opposite flow can be true.

13 LAMBDA has offices in the cities of Maputo (national headquarters responsible for the southern region of the country), Beira (responsible for the central region) and Nampula (responsible for the northern region).

14 Tamale points out that European and North American Africanist anthropologists have already devoted themselves, among other subjects, to the theme of 'dry sex' in Africa (Tamale 2001: 19) and elsewhere (Boellstorff 2005: 101). It is a cultural practice that consists of using herbs to decrease vaginal lubrication in order to obtain more friction and, thus, more sexual pleasure. In the present case, the lubricating gel, on the contrary, is introduced by national and international organisations to replace other substances that are locally used and not safe, as saliva, mayonnaise, oils in general, petroleum jelly, peanut butter, etc. The lubricating gel makes sexual intercourse more and better lubricated and thus produces less friction and cracking and, consequently, less chance of transmitting sexually transmitted diseases. In Mozambique, it is common for LAMBDA leaders to retrieve the story of how they managed a few years ago to unlock a large load of lubricating gel that was stuck on the country's border, due to bureaucratic problems and the authorities' understanding of the importance of such product.

15 Complaints from beneficiaries in this regard can be found in Guambe 2017: 85-6 and in my own Ph.D. thesis (Miguel 2019: 222).

\section{References}

Bleys, R. 1995. The geography of perversion: male-to-male sexual behavior outside the West and ethnographic imagination, 1750-1918. New York: New York University Press.

Boellstorff, T. 2005. The gay archipelago: sexuality and nation in Indonesia. Princeton: Princeton University Press.

Chipenembe, M J. 2018. Sexual rights activism in Mozambique. A qualitative case study of civil society organisations and experiences of 'lesbian, bisexual and transgender persons.' Ph.D. Thesis, Universiteit Gent, Belgium.

Dankwa, S. 2009. 'It's a Silent Trade': Female Same-Sex Intimacies in Post-Colonial Ghana.' NORA Nordic Journal of Feminist and Gender Research 17 (3): 192-205. 
Dearham, K. 2013. 'NGOs and queer women's activism in Nairobi.' In Hakima Abbas and Sokari Ekine (eds), Queer African Reader. Dakar: Pambazuka Press, pp 186-202.

Douglas, M. 1986. How Institutions Think. Syracuse: Syracuse University Press.

Epprecht, M. 2013. Sexuality and Social Justice in Africa: Rethinking Homophobia and Forging Resistence. London: Zed Books.

Foucault, M. 1988. História da sexualidade 1: A vontade de saber. $19^{\text {th }}$ ed. Rio de Janeiro: Graal.

Gaudio, R. 2009. Allah Made Us: Sexual Outlaws in an African Islamic City. Chicester: Wiley-Blackwell. Guambe, A. 2012. Experiências e percepções sobre o uso de insumos de prevenção do HIV e outras ITS em homens que fazem sexo com homens em Maputo entre 2010 a 2012. Masters Dissertation. Universidade Eduardo Mondlane, Mozambique.

2017. Dispositivos em Saúde: um olhar sobre equidade e direitos com homens que fazem sexo com homens em Moçambique. Ph.D. Thesis. Universidade Federal do Rio de Janeiro, Brazil.

Hoad, N. 2007. African intimacies: race, homosexuality and globalization. Minneapolis: University of Minnesota Press.

Leap, W. 2002. 'Studying Lesbian and Gay Languages: Vocabulary, Text-making, and Beyond.' In W Leap and E Lewin (eds), Out in theory: the emergence of lesbian and gay anthropology. Chicago: University of Chicago Press, pp. 128-154

Lyons, $\mathrm{H}$ and A Lyons. 2003. Irregular Connections: A history of Anthropology and Sexuality. London: University of Nebraska Press.

Kendall, K. 1998. 'When a woman loves a woman in Lesotho: Love, Sex, and the (Western) construction of homophobia.' In S Murray and W Roscoe (ed), Boy-wives and female husbands: studies of African homosexualities. New York: Palgrave, pp. 223-241.

Miguel, F. 2019. Maríyarapáxjis: Silêncio, exogenia e tolerância nos processos de institucionalização das homossexualidades masculinas no sul de Moçambique. Ph.D. Thesis. Universidade de Brasília (UnB), Brazil.

Mugabe, N. 2019. A graça da desgraça: socialidades e processos de engajamento no universo LGBT em duas experiências etnográficas no sul global (Rio de Janeiro e Maputo). Ph.D. Thesis. Universidade Estadual do Rio de Janeiro (UERJ), Brazil.

Murray, S and W Roscoe. 1998. Boy-Wives and Female Husbands: Studies of African Homosexualities. New York: Palgrave.

Neill, J. 2009. The Origins and Role of Same-Sex Relations in Human Societies. Jefferson: McFarland \& Company.

Nyanzi, S. 2013. 'Rhetorical Analysis of President Jammeh's Threats to Behaead Homosexuals in the Gambia.' In S N Nyeck and M Epprecht. Sexual Diversity in Africa: Politics, Theory, Citizenship. Québec: McGill-Queen's University Press, pp. 67-87

Padgug, R. 1990. 'Sexual Matters: Rethinking Sexuality in History'. In M Duberman, M Vicinus and G Chauncey (eds), Hidden from History: Reclaiming the Gay and Lesbian Past. New York: Penguin Books, pp. 54-64.

Patton, C. 1992. 'Patton from Nation to Family: Containing “African AIDS.”' In A Parker, M Russo, D Sommer and P Yaeger (eds), Nationalisms and Sexualities. New York: Routledge, pp. 218-235.

Rubin, G. 2018. 'Estudando subculturas sexuais: escavando as etnografias das comunidades gays em contextos urbanos da América do Norte.' Teoria e Cultura 13 (1): 247-288. 
Sousa, D de. 2018. Lecture at the US Embassy. 14 July. Maputo.

Tamale, S. 2011. 'Researching and Theorising Sexualities in Africa.' In S Tamale (ed), African Sexualities: a reader. Cape Town: Pambazuka Press, pp. 11-36.

UNICEF. 2014. Situation Analysis of Children in Mozambique. Maputo: UNICEF.

\section{Interviews}

Paula. 2018. Interview by author. Matola. 30 April.

Caetano. 2018. Interview by author. Maputo. 11 June.

Luiz. 2018. Interview by author. Maputo. 27 June.

Patrick. 2018. Interview by author. 12 July.

Valentina. 2018 Interview by author. Maputo. 31 July.

Jessy. 2018. Interview by author. Maputo. 16 August.

\section{Acknowledgments}

I am grateful not only to the critique of the peer reviewers, to the work of the copyeditor and to the good reception of this paper by the editors of Contexto Internacional, but also to the collaboration and kindness both from my LAMBDA fellows and from the staff of what I hereby call the TLPFA Project. This research was funded by the National Council for Scientific and Technological Development - CNPq.

\section{About the author}

Francisco Paolo Vieira Miguel obtained a Bachelor's degree in Social Sciences from the Federal University of Rio de Janeiro (UFRJ) (2011) and a Master's degree in Social Anthropology from Brasília University (UnB) (2014), whose master thesis was elected the Best Thesis and Dissertation Award for 2014. He is a Doctor in Social Anthropology from the Brasília University (UnB) (2019). He is also a member of the Group of Studies in African Contexts (ECOA/PPGAS/UNB) and a former temporary instructor at the Department of Collective Health (UnB). He is the author of the book 'Levam má bô: homossexualidades masculinas em um arquipélago africano' (2016) and published many scientific papers. His current research interests are on sexuality, gender, history, health, and political movements in African lusophone countries. 


\section{Cooperação Internacional, Homossexualidade e AIDS em Moçambique}

Resumo: O presente é um estudo etnográfico de um projeto de cooperação internacional entre uma organização internacional de luta contra a epidemia do HIV/ AIDS e a organização LAMBDA, a maior ONG LGBT de Moçambique. Os objetivos deste artigo são demonstrar, primeiramente, como, devido ao fluxo internacional de recursos financeiros ligados a certos conceitos/agendas, esses projetos acabam de alguma forma institucionalizando um projeto de homossexualidade em Moçambique, além de reavivar práticas potencialmente neocoloniais. $\mathrm{O}$ trabalho também procura demonstrar como as práticas burocráticas externas podem entrar em choque com as práticas culturais locais, no que tem sido chamado de 'ONGização'.

Palavras-chave: relações internacionais; cooperação; África; Moçambique; AIDS; etnografia; antropologia.

Received on 6 June 2020, and approved for publication on 19 August 2020. 